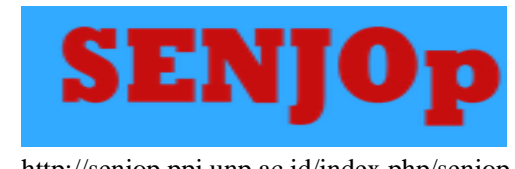

http://senjop.ppj.unp.ac.id/index.php/senjop

\title{
STUDY OF THE POTENTIAL OF KUTA MANDALIKA BEACH GEOCHOLOGY IN CENTRAL LOMBOK DISTRICT
}

\author{
${ }^{*}$ Nilawati $^{1}$ and Olivia Oktorie ${ }^{2}$ \\ ${ }^{1}$ Masters Program in Geography Education (S2), Faculty of Social Sciences, Padang \\ State University \\ ${ }^{2}$ Doctor Program, Environmental Science Program, Universitas Negeri Padang \\ Email: watinila8912@gmail.com
}

*Corresponding Author, Received: Augustus 14, 2019, Revised: October 17, 2019, Accepted: November 11, 2019

\begin{abstract}
This study aims to analyze the geoecological potential of the coast in Central Lombok Regency. The research method uses a survey method by determining the sample by purposive sampling. The analysis unit used is a geoecological unit that is assessed for the potential and constraints of each to develop certain tourism activities. Assessment of potential uses a SWOT analysis (Strength, Weakness, Opportunity, and Threat) to determine the development of coastal areas as opportunities for surrounding communities and sustainable maintenance of resources. The development of tourist areas is able to contribute to local revenues, open business opportunities and employment opportunities and at the same time function to maintain and preserve natural and biological wealth. classification of geoecological units in the Central Lombok coast1). Coastal alluvial geoeconomic units, 2) Valley geoecological units between hills, and 3) Geoecological units of the slopes of the denudational hills.
\end{abstract}

\section{Keywords: Geoecological Potential, Kuta Beach Scandal}

\section{INTRODUCTION}

Indonesia is an archipelago with an entire coastline of $80,791 \mathrm{~km}$. This very long coastline creates sectoral problems in the development and utilization of coastal areas. This is due to the lack of thought for the development of coastal areas holistically (Hermon, et al. 2018; Hermon, 2019). Development of a coastal area holistically will be more beneficial if you use an approach that can bring together influential environmental factors in the coastal area (Kristian and Oktorie. 2018; Oktorie, 2017; Oktorie, 2018; Oktorie, et al., 2019). These factors include the biosphere, toposphere, atmosphere, pedosphere, and hydrosphere. One approach that can integrate these environmental factors is the geoecological approach. 


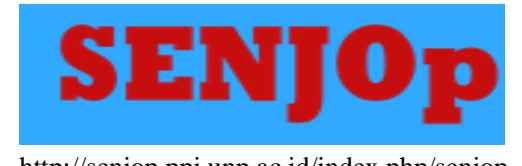

http://senjop.ppj.unp.ac.id/index.php/senjop
Science and Environmental Journals for Postgraduate

Vol. 2 No. 1 (pp.12-18) December 2019

p_ISSN 2655-5085

e_ISSN 2655-5239

Coastal areas in Central Lombok are included in the MCMA (Marine Coastal Management Area) which has the potential to be developed as a tourist area. One area that is already well known is Kuta Mandalika, this tourism development will have a very broad and significant impact on economic development, efforts to preserve natural resources and the environment and will have an impact on the socio-cultural life of the community, especially local communities. The development of tourist areas is able to contribute to local revenues, open business opportunities and employment opportunities and at the same time function to maintain and preserve natural and biological wealth. It is hoped that the development of tourism can have a good influence on the lives of the community, especially the local community and be able to encourage the development of sharing other sectors both economic, social and cultural (Hermon, 2019). Thus, tourism development must be based on sustainability criteria which means that development can be supported ecologically in the long term while being economically feasible, ethically and socially fair to the community. That is, sustainable development is an effort to develop quality of life by regulating the supply, development, utilization and maintenance of resources in a sustainable manner. The number of people who work as traders have hopes that all the merchandise and services they offer to tourists can be satisfying and later tourists will come back again to enjoy the merchandise and services they offer.

\section{METHOD}

This research was conducted in the Kuta beach area of Central Lombok Regency, West Nusa Tenggara Province. The coastal area in this Regency covers four sub-districts namely Sayung District, Karangtengah District, Bonang District, and Wedung District. The material used in this study is Peta Rupa Bumi Indonesia, a scale of 1: 25,000. This RBI map is used as a reference to determine administrative limits, making it easier to make observations. The tools used in this study are computer equipment, GPS (Global Positioning System), stationery and Coastal Integrated Integrated Handbook that are useful in conducting research. The research method used in this study is the survey method. Methods of collecting data by sampling, and the method of analysis qualitatively. The population in this study is all coastal communities and the entire coastal area of the Mandaika beach. The sampling technique is by random sampling method. The technique 


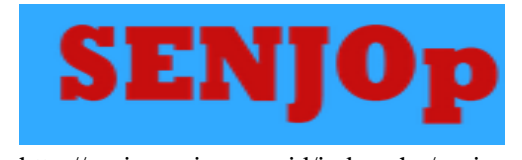

http://senjop.ppj.unp.ac.id/index.php/senjop
Science and Environmental Journals for Postgraduate

Vol. 2 No. 1 (pp.12-18) December 2019

p_ISSN 2655-5085

e_ISSN 2655-5239

of collecting data with secondary data analysis and field observations, and analysis of the results descriptively.

\section{RESULTS AND DISCUSSION}

The area of Central Lombok Regency is located at position 80241 - 80571 LS and 1160051 - 1160241 BT with an area of 1,208.39 km2 (Tourism Statistics of Central Lombok Regency, 2013). Praya City as the Regency Capital with a height of 100 to 200 meters above sea level. The geographical conditions of Central Lombok Regency are quite varied, consisting of hills whose area is included in the area of Mount Rinjani, which is located in the middle of Lombok Island. Then the low land which is the center of agricultural activities which lies in the middle, stretches from north to south. While the coastline stretches from Torok beach Aiq Beleq Praya Barat Daya Subdistrict, Selong Belanak beach, West Praya District, to Bilelando Village, East Praya District. The coastal area of Central Lombok is included in the development area of the Mandalika Kuta Beach Area. The development area of Kuta Mandalika Beach is in the South and North of Senggigi Beach. Administratively, Kuta Lombok is located in the southern part of Central Lombok, Pujut District, Central Lombok Regency, West Nusa Tenggara Province. Kuta is one of the villages located in the coastal area so that it has great potential in developing tourism activities.

Hugget (1995); Hermon (2012); Hermon (2014); Hermon (2015); Hermon (2016); Hermon (2017) geoecology is a study of the structure and function of ecosystems. Geoekologi system is an ecological unity system consisting of landscape components and processes in it. Geoecological approaches emphasize natural landscapes and landscapes that have been affected by human activities. Geoecology studies can be used to identify landscape potential and risks. Climate in the research area, Central Lombok regency has D climate and E climate, namely tropical rain with dry dry season, ie from November to May, while Rainfall ranges from 2,500 mm per year. The average temperature throughout the year ranges from 24.7 s.d. 26.8 C. From the geological aspect, the material in this area is dominated by volcanic material. The material in the form of pyroclastic consists of tuff, volcanic breccia, and beach sand. The main source of the material is Rinjani Volcano. Especially for coastal sand deposits that are white, the material comes from the results of 


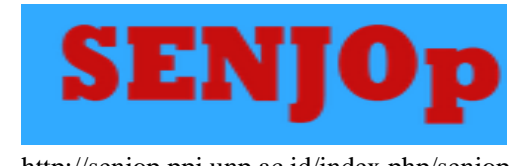

http://senjop.ppj.unp.ac.id/index.php/senjop
Science and Environmental Journals for Postgraduate

Vol. 2 No. 1 (pp.12-18) December 2019

p_ISSN 2655-5085

e_ISSN 2655-5239

coral wreckage. This white sand deposit mixed with black sand originating from the Rinjani volcano and deposited to form its own rustic.

The water system in the study area is influenced by 3 Watersheds (DAS), namely the White Watershed in the North, the Jongkok Watershed in the middle, and the Dodokan Watershed in the South. Flow fluctuations in the rivers are quite large, for example on the Dodokan River, the flow rate in the rainy season reaches $113.63 \mathrm{~m} 3 / \mathrm{sec}$, but in the dry season only $0.68 \mathrm{~m} 3 / \mathrm{sec}$. This shows that the river catchment areas of the rivers are less able to store water. Springs can be found on hillsides and are found most in the Squat watershed. Springs discharge varies between $751 /$ dt to 4001 / s. Groundwater found has a depth of between $0.8 \mathrm{~m}$ and $7.8 \mathrm{~m}$. This groundwater is mostly used by residents, restaurants, and hotels that are often found in the area.

Oceanographic characteristics of the coastal areas of Central Lombok are influenced by several factors, namely wind, the process that takes place on the beach. Wind speeds ranging from $0.2 \mathrm{ml} / \mathrm{s}$ to $3.3 \mathrm{~m} / \mathrm{dt}$, are included in the gentle category to very weak. The direction of the blow varies, namely north to southeast. The wave height is relatively not too high, which is $0.1 \mathrm{~m}$ to $1.5 \mathrm{~m}$, with a wave period of 2.8 seconds to 5.0 seconds. The dominant vegetation in this area is coconut. The spread of coconut plants is very wide, starting from the hills. Other types of vegetation include bamboo, bananas, jackfruit, grass, mangroves.

Geoecological analysis requires data on abiotic, biotic, and cultural factors (Hermon, 2010; Hermon, 2011; Hermon et al, 2017). Abiotic components include geology (rock), soil, climate, topography, hydrology (water), and oceanology. The data is adjusted to the landscape in the study area. Kuta Mandalika Beach has three main landscapes, namely volcanic, maritime, and fluvial landscapes. The abiotic component data is then processed to limit landform units. The landform unit is a spatial unit that will be used in the analysis Geoecology. Abiotic components can be divided into flora and fauna. The flora and fauna data used are native flora / fauna data. The native flora and fauna shows the characteristics of the original ecosystem of the landscape. Cultural components are the influence of human activities such as land use, conservation efforts, and other forms of influence on human activities. Data on flora, fauna and the influence of human activities produce a description of the ecology of the study area. The existing 


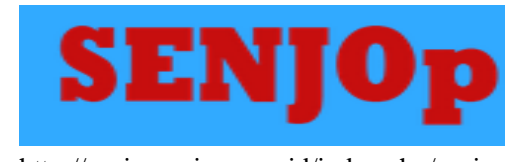

http://senjop.ppj.unp.ac.id/index.php/senjop
Science and Environmental Journals for Postgraduate

Vol. 2 No. 1 (pp.12-18) December 2019

p_ISSN 2655-5085

e_ISSN 2655-5239

landforms are generally the result of volcanic processes, with variations in the formation process in the form of marine processes, fluvial processes, and denudational processes. The marine process produces the formation of rustic and alluvial plains of the coast. The fluvial process produces alluvial plains. The denudational process produces valleys between hills, hills and hills, and denudational hills (Hermon et al, 2018; Hermon, 2019; Hermon, et al., 2019). The steepness of the hillside averages $>30 \%$ and the process of erosion and landslides takes place intensively. The deposition process produces a land where the area is relatively narrow, because the foothills generally meet directly with the coastline. In the physical area, the erosion process has occurred in many places, even though it is still within safe limits. At the foot of the hill facing the coastline, landslides have also been found. This process is generally found on cliffs that are trimmed for road poaching (Linsey, 1980; Hermon, 2019). Fluvial landscapes are often associated with sunagi and watershed. The area of river water is a landscape in the form of a basin and is limited by topography, storing and flowing rainwater through rivers or creeks and through a single outlet in the sea.

\section{CONCLUSION}

Geoecological analysis requires data on abiotic, biotic, and cultural factors. Abiotic components include geology (rock), soil, climate, topography, hydrology (water), and oceanology. The data is adjusted to the landscape in the study area. Kuta Mandalika Beach has three main landscapes, namely volcanic, maritime, and fluvial landscapes. The abiotic component data is then processed to limit landform units. The landform unit is a spatial unit that will be used in geoecological analysis. Kuta Mandalika area is a tourism development center in Central Lombok. The development of Kuta Mandalika will also have an impact on other tourism objects around it. For this reason, the management of coastal areas in Central Lombok needs to pay attention to the diversity of potential and developing tourism activities. Management includes aspects of monitoring and control, infrastructure development, and environmental safety. 


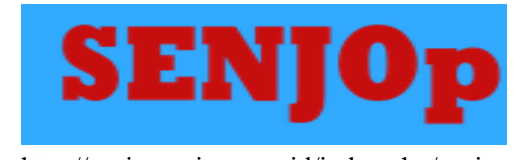

http://senjop.ppj.unp.ac.id/index.php/senjop

\section{REFERENCES}

Andreev, V. I. and Nikolaeva, A.G.. 2012. The Geoecological Impact of Eruptions on Karymskii Volcano and Tokareva Crater, Eastern Kamchatka: The 1996 - 2008 Observations. Journal of Volcanology and Seismology, 2012, Vol. 6, No. 6, pp. $329-340$.

Bubnova, M. B. and Ozaryan, A.Y 2012. Geoecological Valuation of Natural-and-Mine Engineering Systems on the South of the Far East. Journal of Mining Science, 2012, Vol. 48, No. 5, pp. $941-946$.

Broothaerts, N, et al .. 2013. Sensitivity of floodplain geoecology to human impact: A Holocene perspective for the headwaters of the Dijle catchment, central Belgium.The Holocene 23(10) 1403 - 1414.

Dahuri, R., Rais, J., Ginting, S.P, dan Sitepu, M.J., 1996, Pengelolaan Sumberdaya Wilayah Pesisir dan Lautan Secara Terpadu, PT Pradnya Param ita, Jakarta. Djumirah, 1997, Studi Airtanah di Kawasan Wisata Pantai Senggigi Lombok NTB,

Emelyanov, E. M. 2012. The geochemical and geoecological situation in the aras of the Skagerrak and the Baltic Sea where Chemical munition was dumped. Journal GEOLOGIJA. 2007. No. 59. P. 8 - 29.

Hermon, D. 2010. Geografi Lingkungan: Perubahan Lingkungan Global. UNP Press.

Hermon, D. 2011. Studi Karakteristik Epipedon berdasarkan Penggunaan Lahan di Kecamatan X Koto Kabupaten Tanah Datar. Universitas Andalas.

Hermon, D. 2012. Mitigasi Bencana Hidrometeorlogi: Banjir, Longsor, Degradasi Lahan, Ekologi, Kekeringan, dan Puting Beliung. UNP Press. Padang.

Hermon, D. 2014. Impacts of Land Cover Change on Climate Trend in Padang Indonesia. Indonesian Journal of Geography. Volume 46. Issue 2. p: 138-142. Fakultas Geografi Universitas Gajah Mada.

Hermon, D. 2015. Geografi Bencana Alam. Jakarta: PT RajaGrafindo Persada.

Hermon, D. 2016. Mitigasi Perubahan Iklim. Rajawali Pers (Radjagrafindo).

Hermon, D. 2017. Climate Change Mitigation. Rajawali Pers (Radjagrafindo).

Hermon, D., P. Iskarni., O. Oktorie and R. Wilis. 2017. The Model of Land Cover Change into Settlement Area and Tin Mining and its Affecting Factors in Belitung Island, Indonesia. Journal of Environment and Earth Science. Volume 7 No. 6. p: 32-39. IISTE.

Hermon, D., Ganefri., A. Putra and O. Oktorie. 2018. The Model of Mangrove Land Cover Change for the Estimation of Blue Carbon Stock Change in Belitung Island-Indonesia. International Journal of Applied Environmental Sciences. Volume 13. Issue 2. p: 191-202. Research India Publication.

Hermon, D., A. Putra and O. Oktorie. 2018. Suitability Evaluation of Space Utilization Based on Enviromental Sustainability at The Coastal Area of Bungus Bay in Padang City, Indonesia. International Journal of GEOMATE. Volume 14. Issue 41. p: 193-202. Geomate International Society.

Hermon, D. 2019. Evaluation of Physical Development of The Coastal Tourism Regions on Tsunami Potentially Zones in Pariaman City-Indonesia. International Journal of GEOMATE. Volume 17. Issue 59. p: 189-196. Geomate International Society. 


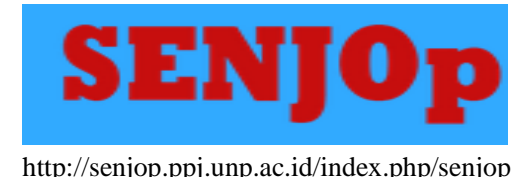

Science and Environmental Journals for Postgraduate

Vol. 2 No. 1 (pp.12-18) December 2019

p_ISSN 2655-5085

e_ISSN 2655-5239

Hermon, D. 2019. Mitigation and Adaptation: Disaster of Climate Change. Sara Book Publication. India.

Hermon, D. 2019. Characteristics of Melanic Epipedon Based on Biosequence in The Physiography of Marapi-Singgalang, West Sumatra. IOP Conference Series: Earth and Environmental Science. Vol. 314. Issue 1.

Hermon, D., Erianjoni, I. Dewata, A. Putra, and O. Oktorie. 2019. Liquefaction Vulnerability Analysis as a Coastal Spatial Planning Concept in Pariaman CityIndonesia. International Journal of Recent Technology and Engineering (IJRTE). Vol. 8. Issue 2. Pp 4181-4186.

Hermon, D. 2019. Land Stability Model for Sustainable Spatial Planning in Padang CityIndonesia based on Landslide Disaster. Journal of Geography and Earth Sciences. Vol. 7. Issue 1. Pp 19-26.

Huggett, RJ. 1995. Geoecology: An Evolutionary Approach (first Edition) . England: Routledge. Santosa, LW. 2010. Pengaruh genesis bentuklahan terhadap hidrostratigrafi dan hidrogeokimia dalam evolusi airtanah bebas. Kasus: bentanglahan kepesisiran kabupaten kulonprogo DIY. Yogyakarta: Fakultas Geografi, Program Pascasarjana UGM.

Kristian, A and O. Oktorie. 2018. Study of Coastal Mangrove Conservation in the World. Sumatra Journal of Disaster, Geography and Geography Education. Volume 2. Issue 1. p: 49-52.

R.J Nugget, Geoecology: An Evolutionary Approach, 1997 The Indonesian Journal of Geography 27(70) Verstappen, CF. 1937. Outline Of The Geomorphlogy of Indonesia a Case Study on Tropical Geomorphology of a Tectogene Region. Netherlands: ITC .

Oktorie, O. 2017. A Study of Landslide Areas Mitigation and Adaptation in Palupuah Subdistrict, Agam Regency, West Sumatra Province, Indonesia. Sumatra Journal of Disaster, Geography and Geography Education. Volume 1. Issue. 1. p: 43-49. Master Program of Geography Education.

Oktorie, O. 2018. Model Kebijakan Responsif Pemulihan Bencana Letusan Gunung Sinabung. Jurnal Kapita Selekta Geografi. Volume 1. Issue 1. p: 15-20.

Oktorie, O., D. Hermon, Erianjoni, A. Syarief and A. Putra. 2019. A Calculation and Compiling Models of Land Cover Quality Index 2019 uses the Geographic Information System in Pariaman City, West Sumatra Province, Indonesia. International Journal of Recent Technology and Engineering (IJRTE). Vol. 8. Issue 3 pp. 6406-6411.

Rangkuti, F., 1997, Analisis SWOT: Teknik Membedah Kasus Bisnis, PT Gramedia Pustaka Utama, Jakarta. 